Pesq. Vet. Bras. 36(Supl.1):89-94, junho 2016 DOI: $10.1590 / \mathrm{S} 0100-736 \mathrm{X} 2016001300013$

\title{
Ultrastructural analysis of the spermatogenesis in the guinea pig (Cavia porcellus) ${ }^{1}$
}

\author{
Luciana S. Simões ${ }^{2}$, Rose E.G. Rici², Phelipe O. Favaron ${ }^{2 *}$, Taís Harumi de Castro \\ Sasahara $^{3}$, Rodrigo S.N. Barreto ${ }^{2}$, Jessica Borghesi ${ }^{2}$ and Maria A. Miglino ${ }^{2}$
}

\begin{abstract}
Simões L.S., Rici R.E.G., Favaron P.O., Sasahara T.H.C., Barreto R.S.N., Borghesi J. \& Miglino M.A. 2016. Ultrastructural analysis of the spermatogenesis in the guinea pig (Cavia porcellus). Pesquisa Veterinária Brasileira 36(Supl.1):89-94. Departamento de Cirurgia, Faculdade de Medicina Veterinária e Zootecnia, Universidade de São Paulo, Av. Prof. Dr. Orlando Marques de Paiva 87, Cidade Universitária, São Paulo, SP 05508-270, Brazil. E-mail: phelipe.favaron@yahoo.com.br

Understanding of the reproductive function is essential for both, the establishment of appropriate management systems, and for the use of new species as animal models. In this study, we used light and electron microscopy to characterize the sexual development stages of the guinea pig (Cavia porcellus) in specimens of 30, 45 and 90 days of age. We observed the differentiation of spermatocytes only through transmission electron microscopy in the leptotene, zygotene and pachytene phases of meiosis, in 30-day-old animals. During puberty, there was differentiation of the germinative epithelium and formation of the acrosome. Spermatozoa, however, were not detected. Thus, we could infer that puberty happens after 45 days of age. Sexual maturity was evident in 90-day-old specimens. Our results showed that changes in the testicular germinative epithelium during the postnatal sexual development in guinea pig led to morphological changes, including the ones related to the development of Leydig and Sertoli cells, which are directly related to puberty. In this work, we provide new morphological subsidies for a better understanding of reproductive parameters of this species, enabling its use as an animal model in the field of the reproductive biology.
\end{abstract}

INDEX TERMS: Reproduction, meiosis, guinea pig, animal models.

RESUMO.- [Análise ultraestrutural da espermatogênese do porquinho-da-Índia (Cavia porcellus).] A função reprodutiva é um fator de vital compreensão tanto para o estabelecimento de sistemas apropriados de manejo, quanto para o uso de novas espécies como modelos animais. Neste estudo através da microscopia de luz e eletrônica caracterizou-se a fase de desenvolvimento sexual do porquinho-da-Índia (Cavia porcellus) em espécimes de 30, 45 e 90 dias de desenvolvimento. Nos animais de 30 dias, a diferenciação dos espermatócitos foi visualizada somente na microscopia eletrônica de transmissão em leptóteno, zigóteno e paquí-

\footnotetext{
${ }^{1}$ Received on March 4, 2016.

Accepted for publication on April 13, 2016.

${ }^{2}$ Departamento de Cirurgia (VCI), Faculdade de Medicina Veterinária e Zootecnia (FMVZ), Universidade de São Paulo (USP), Av. Prof. Dr. Orlando Marques de Paiva 87, Cidade Universitária, São Paulo, SP 05508-270, Brazil. *Corresponding author: phelipe.favaron@yahoo.com.br

${ }^{3}$ Departamento de Morfologia e Fisiologia Animal, Universidade Estadual Paulista "Júlio de Mesquita Filho" (Unesp), Av. Prof. Paulo Donato Castellane s/n, Jaboticabal, SP 14884-900, Brazil.
}

teno. Durante a puberdade, houve diferenciação do epitélio germinativo, formação do acrossoma, porém não foram evidenciados espermatozóides, assim, infere-se que a puberdade acontece a partir dos 45 dias de idade. A maturidade sexual foi evidente aos 90 dias de idade. Nossos resultados mostraram que ao longo do desenvolvimento sexual pós-natal do porquinho-da-Índia, mudanças no epitélio germinativo testicular levam há alterações morfológicas, inclusive com relação ao desenvolvimento das células de Sertoli e de Leydig, as quais estão diretamente relacionadas com a puberdade. Assim, novos subsídios morfológicos são fornecidos para um melhor entendimento dos parâmetros reprodutivos desta espécie, a fim de viabilizar sua utilização como modelo animal no campo da biologia reprodutiva.

TERMOS DE INDEXAÇÃO: Reprodução, meiose, porquinho-daíndia, modelos animais.

\section{INTRODUCTION}

Rodents, due to their diversity, biology and physiology, have become useful for several research purposes. They 
have been used as homologous models for several human diseases; such as type 1 diabetes, tuberculosis and scurvy, as well as for the understanding of the reproductive biology and complications during pregnancy (Meyrs 2000). There are approximately 235 species of rodents, distributed in 71 genera. In Brazil, wild rodents correspond to $36 \%$ of the fauna (Oliveira 2006). Data on the biology and reproductive physiology in mammals are still scarce, including those related to basic reproductive parameters of wild species, whose relevance and comparative evolution is essential to the current conservation policies (Wildt 2010).

The implications of the characterization of stages of sexual development, such as aspects related to spermatogenic activity, are essential for the knowledge of reproductive biology of any species, regardless of its economic interest (Anann \& Schanbacher 2000). Understanding the reproductive function is essential for both the establishment of appropriate management systems, and for the use of a species as animal models in studies about reproduction. In this sense, knowledge on spermatogenesis, defined as a synchronic process with regular cellular differentiation by which a spermatogonium trunk is gradually differentiated in a highly specialized haploid cell (the sperm) (França \& Russell 1998), is important for the identification of potential causes of infertility and subfertility, and for the understanding of the processes that define sperm production ability (Junqueira \& Carneiro 2013).

The spermatogenesis occurs in the seminiferous tubules, which is, in the majority of species, the main component of the testicular parenchyma. Considering that the testicular mass reflects directly on sperm production, the variation in the proportion of seminiferous tubules among various species can be considered as one of the main factors responsible for the differences observed in the efficiency of spermatozoa production. Although the spermatogenic activity is relatively constant in sexually mature animals, it presents expressive variations among species and among the lineages or breeds (França \& Russell 1998).

Once it is extremely sensitive to chemotherapy, hormone treatment and temperature, and due to the fact that the recovery of the spermatozoa production depends on the regeneration of stem cells, the spermatogenesis has been studied in several species of rodents, because their extraordinary reproductive capacity in a wide range of climatic conditions makes them interesting models (Santos et al. 2013, Meyrs 2000), assuring significant importance in biomedical research and laboratory tests. Among these species, the guinea pig has been used as animal model since the end of the 18th century, and its importance in scientific research is increasing (Suzuki et al. 2003). Its long gestation period, spontaneous ovulation and active corpus luteum make it an excellent animal model for the study of human reproduction. The physiology of the reproductive system of the male guinea pig has been insufficiently described. Especially related to the guinea pig, there are some gaps in the literature regarding to the morphology and ultrastructure of the testis, although there are some studies focusing on quantification of cell types at different sexual stages (Hess \& França 2008), accessory glands (Váquez \&
Del Sol, 2010, Gradela et al. 2013), effects of electromagnetic fields on testis (Farkhad et al. 2007), and more recently the effects of fluoride and aluminum in the expression of StAR and P450scc in the testis (Dong et al. 2016).

In this context, the objective of this research was to carry out a detailed study on the spermatogenesis in the guinea pig (Cavia porcellus) using ultrastructural analyses of the testis at 30,45 , and 90 days of age. We intend to generate subsidies for a better understanding of reproductive parameters and enable its use as an animal model in reproductive studies.

\section{MATERIALS AND METHODS}

We used 12 guinea pig testicles at 30 (pre-pubescent, $n=4$ ), 45 (pubescent, $n=4$ ), and 90 (adult, $n=4$ ) days of age according to Santos et al. (2011). The average weight of the individuals were $248 \mathrm{~g}, 262 \mathrm{~g}$ and $582 \mathrm{~g}$, respectively. The animals were purchased in a commercial pet shop and kept in the School of Veterinary Medicine and Animal Science of the University of Sao Paulo (FMVZ-USP). For sample collection, the animals were anesthetized at the following dosages: ketamine 75-100 mg/kg intraperitoneal (IP); and xylazine 10mg/ $\mathrm{kg}$ IP, and then the testicular orchiectomy was performed. The research was approved by the Ethics Committee for Animal Experimentation of the FMVZ-USP (Protocol number 8735070714).

Samples for histology were fixed in 4\% paraformaldehyde, washed in PBS and dehydrated in a crescent concentration of alcohol (70-100\%), 15 min per concentration. Then, the samples were diaphanized in xylene for $10 \mathrm{~min}$, and embedded in paraffin (Paraplast; Oxford Labware, St Louis, MO, USA). The blocks were sectioned at 5 $\mu \mathrm{m}$ in an automatic microtome (RM2155, Leica, Berlin, Germany) and stained with hematoxilin and eosin (Tolosa et al. 2003). Then, sections were examined in Olympus BX40 microscope (Zeiss KS400 image analysis system 3.4; Carl Zeiss Vision, Munich, Germany).

For transmission electron microscopy, testicular fragments were collected and fixed in $2.5 \%$ glutaraldehyde, washed three times during 10 minutes in $0.1 \mathrm{M}$ phosphate buffer (PBS) and post fixed in $1 \%$ osmium tetroxide. They were immersed in an aqueous solution of $5 \%$ uranyl acetate at room temperature for one hour. After washes in phosphate PBS, the fragments were dehydrated in increasing series of alcohol (70\%-100\%) and washed with propylene oxide. The fragments remained under rotation in 1:1 propylene oxide and resin for 12 to 16 hours. This mixture was replaced by pure resin for 4 to 5 hours. After this period, the samples were embedded in pure resin to make the molds. Once embedded, the fragments remained at $60^{\circ} \mathrm{C}$ for 72 hours. The blocks were cut at $0,5 \mu \mathrm{m}$ of thickness in a ultramicrotome (LEICA ULTRACUT UCT ${ }^{\circledR}$ ), placed in slides and stained at hot $1 \%$ sodium borate solution with $0.25 \%$ toluidine blue in distilled water, for observation under a light microscope (Eclipse 80i Nikon). Ultrathin sections of the resin block (60n thick) were harvested in copper screens and contrasted with $2 \%$ uranyl acetate in distilled water for 5 minutes and $0.5 \%$ lead citrate in distilled water for $10 \mathrm{~min}$. The images were obtained in transmission electron microscopy (Morgagni 268D).

In addition, fragments fixed in $2.5 \%$ glutaraldehyde were washed in PBS, fractured in liquid nitrogen, dehydrated in increasing series of alcohol (70-100\%) and oven-dried at $37^{\circ} \mathrm{C}$ for scanning electron microscopy. The fragments were adhered with carbon glue to metallic stubs and gold coated in metalizer (EMITECH 550 ). The images were obtained by a scanning electron microscope (Leo 435 VP).

\section{RESULTS}

In 30-day-old animals, we observed under light microscopy the clear presence of light and dark spermatogonia in the 
seminiferous epithelium (Fig.1A,B) and the beginning of the differentiation of spermatocytes in leptotene, zygotene and pachytene (Fig.1A,B), which were confirmed by transmission electron microscopy (Fig.1C,D). The Sertoli cells showed an evident pyramid-shaped nucleus with cytoplasmatic projections directed to the lumen (Fig.1B,C). In scan- ning electron microscopy, we observed the proliferation of germinative epithelium, but not the supporting cells in the lumen of the seminiferous tubule (Fig.1E,F).

We observed in 45-day-old animals the proliferation and the differentiation of the germinative epithelium, spermatocytes and spermatogonia, as well as Sertoli cells
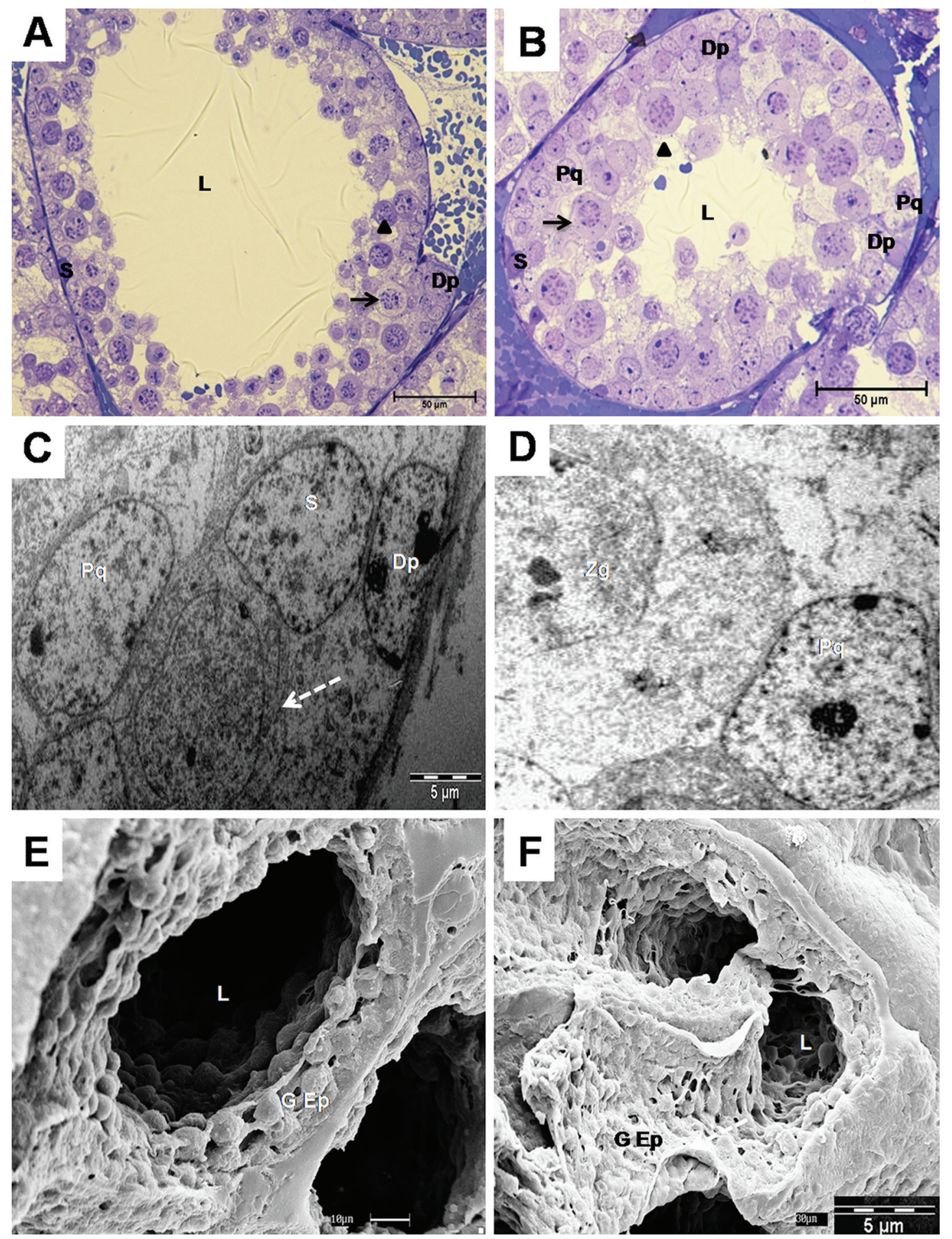

Fig.1. Testis of guinea pig (Cavia porcellus) at 30 days of age. (A,B) Light microscopy. Note the luminal opening of the seminiferous tubules (L), spermatocytes differentiated in diplotene (Dp) and pachytene (Pq), spermatogonia type A (arrows) and B (arrowhead) and Sertoli cells (S). Toluidin blue. (C,D) Transmission electron microscopy. Note the pachytene (Pq), diplotene (Dp), and zygotene (Zq) cells, which showed a rounded nucleus with dispersed cromatin inside. (E,F) Scanning electron microscopy. Details of the germinative epithelium (GEp) and the luminal opening (L). 
(Fig.2A,B). We could characterize the germinative epithelium in cell differentiation under scanning electronic microscopy (Fig.2C,D). Through transmission electron microscopy, we found spermatocytes in meiotic division (Fig.2E), in pachytene and diplotene (Fig.2F), as well as the differentiation of spermatid from the second meiotic division, which showed a spherical nucleus and condensed chromatin near to nuclear envelope, showing the formation of the acrosome and nuclear organization (Fig.3A,B). The formation of pro acrosomic vesicles was visualized (Fig.3B). With the development of spermatogenesis, the nucleus has become oval and smaller, and the cytoplasm began to peel off. At this stage, the stretching of spermatid began (Fig. $3 \mathrm{C}$ ).

In 90-day-old animals, the seminiferous epithelium
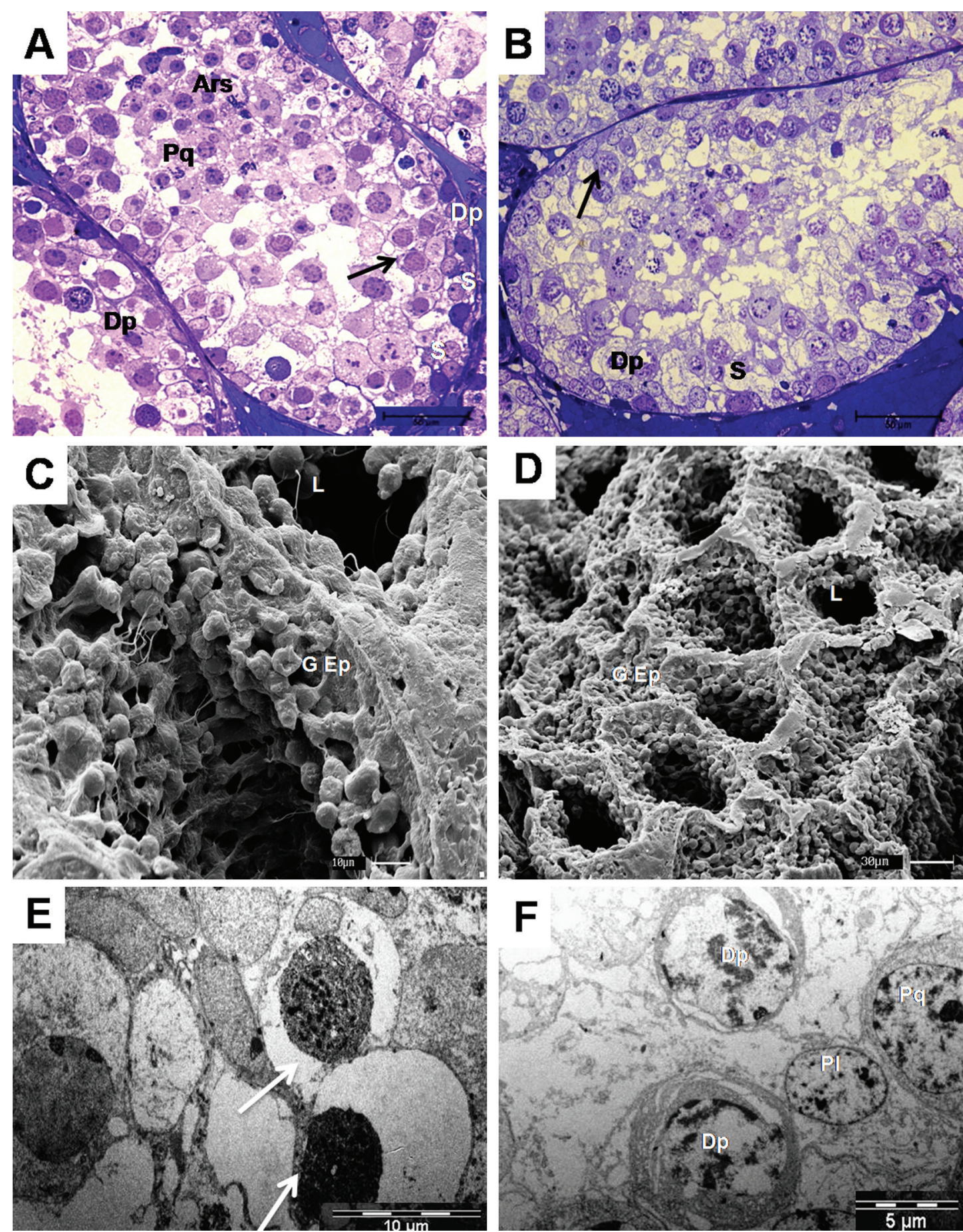

Fig.2. Testis of guinea pig (Cavia porcellus) at 45 days of age. (A,B) Light microscopy. Note the diplotene (Dp) and pachytene (Pq), spermatogonia type A (arrows) and B (arrowhead), rounded spermatid (Rs), and Sertoli cells (S). Toluidine blue. (C,D) Scanning electron microscopy showing the seminiferous tubules with lumination (L) and the differentiation of the seminiferous germinative epithelium (GEp). (E,F) Transmission electron microscopy. (E) Undifferentiated spermatocytes (arrows). (F) Pachytene (Pq), pre-leptotene $(\mathrm{Pl})$, and diplotene (Dp). 

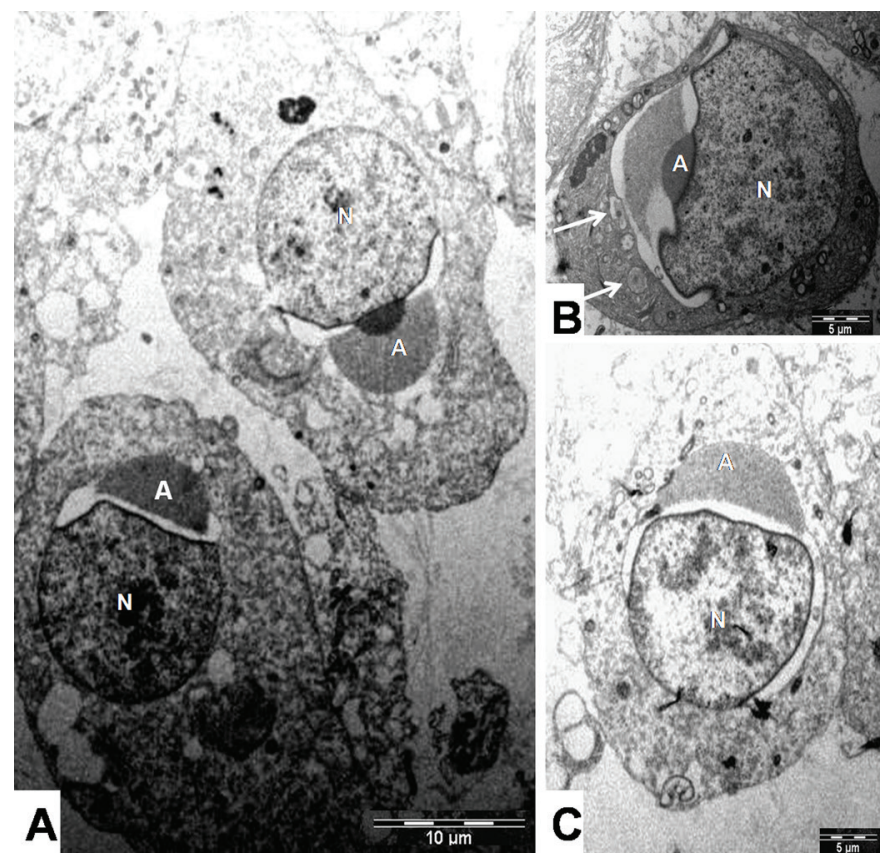

Fig.3. Transmission electron microscopy characterizing the meiotic division of spermatids in 45-day-old guinea pig. (A) Condensation and lengthening of acrosome (A) and nucleus (N). (B) Pro acrosomic vesicles (arrows) and acrosome (A) and nucleus (N). (C) Spermatids in process of lengthening. Note acrosome $(\mathrm{A})$ and nucleus $(\mathrm{N})$.

showed a distinctive appearance, with the presence of all germinative cells (Fig. 4 A), which was composed by spermatogonia, spermatocytes and spermatids. The presence of spermatozoon in the lumen of the seminiferous tubules was also observed (Fig. $4 \mathrm{~A}-\mathrm{C}$ ). The process of spermiation was characterized by transmission electron microscopy, which showed the maturation and expulsion of the sperm to the tubular lumen (Fig.4C).

\section{DISCUSSION}

We suggested that the guinea pig (Cavia porcellus) shows characteristics of experimental interest for reproductive and molecular studies due to the presence of miotic stages: leptotene, zigotene and pachytene, as they occur in other species, including in human (Graur et al. 1991). In humans and rodents, the maturation of testis germinative cells is subdivided into three phases: proliferative (spermatogonia), meiotic (spermiation), and spermiogenic (spermatids), and they all culminate in the spermiation (Santos et al. 2013). We have identified two classes of spermatogonia, and named them types A and B. In contrast of the Spix's yellow-toothed cavy (Galea spixii) for what were identified three types of spermatogonia, type A (dark), A (pale) and B (Santos et al. 2013). In addition, our results showed that these went through several mitotic divisions before entering meiotic prophase as spermatocytes pre-leptotenes, which maturate in leptotene, zygotene and pachytene (phases of meiosis). At the end of the meiotic prophace, these cells are submitted to haploid spermatids and the core of germinative cells is remodeled and compressed, as observed in adult sperm (Cooke \& Saunders 2002).
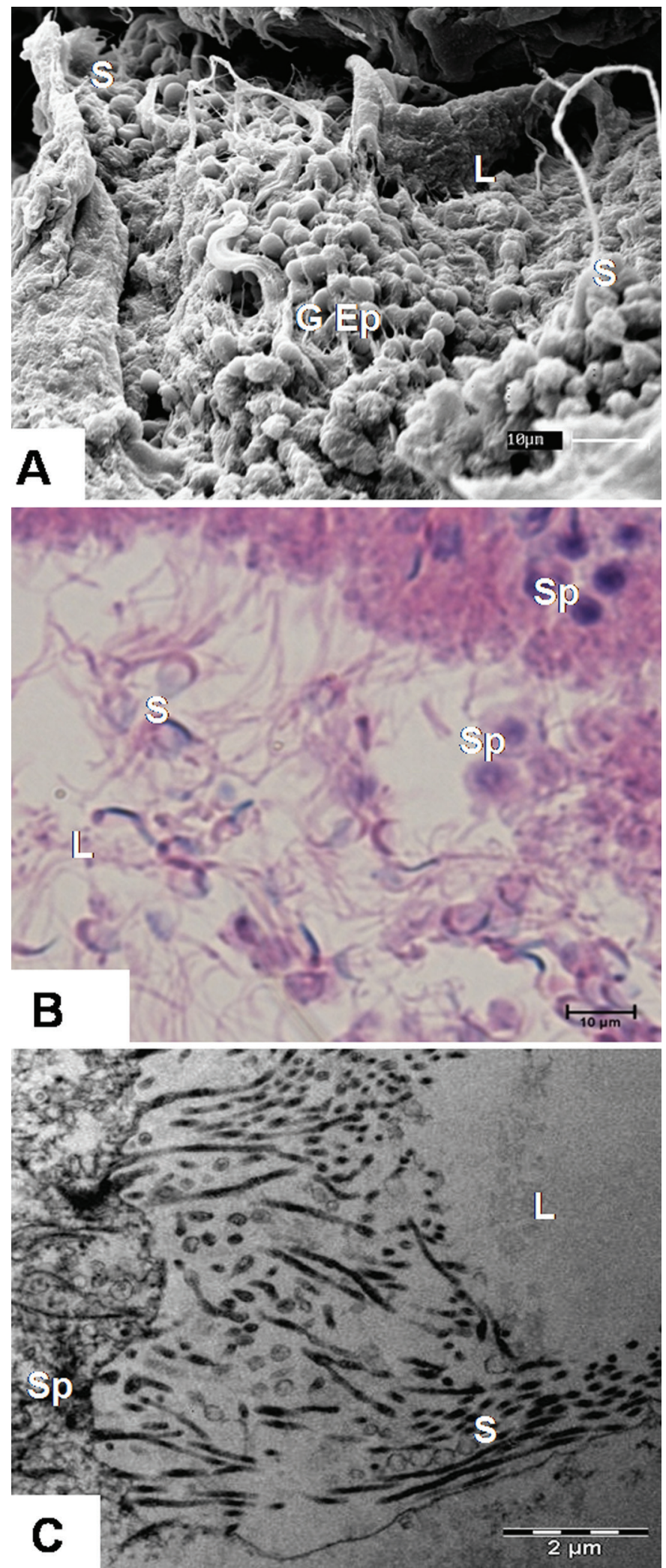

Fig.4. Testis of guinea pig (Cavia porcellus) at 90 days of age. (A) Scanning electron microscopy showing the spermatozoon (S), lumen (L), and germinative epithelium (GEp). (B) Light microscopy. Note the spermatid (Sp), spermatozoon (S) and lumen (L). Hematoxilin and eosin. (C) Transmission electron microscopy showing the process of differentiation of the spermatid (Sp), which form the spermatozoon (S) in the lumen (L). 
Through qualitative analysis of spermatogenesis progress in agoutis (Dasyprocta aguti), it was evaluate the lumination aspects of seminiferous tubules, as well as the presence of primary spermatocytes, spermatids and the formation of first stages of seminiferous epithelium cycle. The puberty of the agouti occurred at seven months old, and it is complete at nine months (Assis Neto et al. 2003). In our studies, we observed the differentiation of spermatid in 45-day-old guinea pigs, and the presence of spermatozoa was seen in 90-day-old animals.

The postnatal development of testis in chinchilla rabbits (Chinchilla chinchilla) was studied in order to determine the period of differentiation of gonocytes for spermatogonia, which occur at 50 days of age. It was also demonstrated that the period of differentiation and apoptosis of these cells, as well as the initiation of spermatogenesis, occurs at day 60 (Vigueras-Vilaseñor, et al. 2013). Herein, we observed the germinative epithelium with spermatogonia in 30-day-old guinea pig, and noticed through light microscopy two types of spermatogonia: clear (type A) and dark (type B). However, we visualized through electron transmission microscopy the beginning of the differentiation of the germinative epithelium in spermatogonia and spermatocytes in all meiotic division phases, from the age of 45 days on. At 90 days of age, there was complete differentiation of the germinative epithelium with the presence of sperm in the lumen of seminiferous tubule.

Finally, as demonstrated by Nunes et al. (2013), the $\mathrm{Ca}$ via porcellus in post-pubertal stage 2 are an advantageous experimental model to address studies on the processes of homologous recognition, alignment, and synapsis during meiotic prophase, as well as for other topics related to male reproductive characteristics.

\section{CONCLUSIONS}

Our results confirm data from the literature about the relationship and the sequence of differentiation stages of the different cell types present in the seminiferous epithelium during sexual development in the guinea pig.

In 30-day-old animals the differentiation of spermatocytes was visualized only through transmission electronic microscopy in the leptotene, zygotene and pachytene.

The differentiation of the germinative epithelium and formation of the acrosome occurred during puberty, however spermatozoa were not evident, indicating that the onset of puberty occurs after 45 days of age.
The development and maturation of both Leydig and Sertoli cells characterized the phase of puberty and sexual maturity, which was evident at 90 days of age.

In this study, new morphological subsidies are provided and discussed for what is known for other species, in order to promote understanding of reproductive parameters of this species, enabling its use as an animal model in the field of the male reproductive biology.

\section{REFERENCES}

Assis-Neto A.C., Carvalho M.A.M., Miglino M.A., Oliveira M.F., Menezes D.J., Papa P.C. \& Kfoury Júnior J.R. 2003. Análise qualitativa do estabelecimento da espermatogênese em cutias (Dasyprocta aguti) criadas em cativeiros. Braz. J. Vet. Res. Anim. Sci. 40:180-184.

Dong C., Cao J., Cao C., Han Y., Wu S., Wang S. \& Wang J. 2016. Effects of fluoride and aluminum on expressions of StAR and P450scc of related steroidogenesis in guinea pigs' testis. Chemosphere 147:345-51.

Farkhad S.A., Zare S., Hayatgeibi H. \& Qadiri A. 2007. Effects of extremely low frequency electromagnetic fields on testes in guinea pig. Pak. J. Biol. Sci. 10:4519-4522.

França L.R \& Russell L.D. 1998. The Testis of Domestic Mammals: male reproduction, a multidisciplinary overview. Churchill Communications, Madrid, p.198-219.

Gradela A., Nunes A.K.R., Matos M.H.T., Franzo V.S., Faria M.D., Moreira M.B \& Santos J.M. 2013. Descrição morfológica e morfométrica da glândula vesicular de cobaias durante o desenvolvimento pós-natal. Pesq. Vet. Bras. 33:942-948.

Graur D., Hide W.A. \& Li W.H. 1991. Is the guinea pig a rodent? Nature 351:649-652.

Hess R.A. \& Franca R. L. 2008. Spermatogenesis and cycle of the seminiferous epithelium. Adv. Exp. Med. Biol. 636:1-15.

Junqueira L.C. \& Carneiro J. 2013. Basic Histology. Guanabara Koogan, Rio de Janeiro, p.323-334.

Oliveira J.A. \& Bonvicino C.R. 2006. Mammals of Brazil: Order Rodentia. Imprensa da UEL, Londrina, p.347-406.

Santos P.R., Carrara T.V., Silva L.C.S., Silva A.R., Oliveira M.F. \& Assis Neto A.C. 2011. Caracterização morfológica e frequência dos estádios do ciclo do epitélio seminífero em preás (Galea spixii Wagler, 1831) criados em cativeiro. Pesq. Vet. Bras. 31:18-24.

Santos P.R., Oliveira M.F., Arroyo M.A., Silva A.R., Rici R.E., Miglino M.A. \& Assis Neto A.C. 2013. Ultrastructure of spermatogenesis in Spix's yellow-toothed cavy (Galea spixii). Reproduction 147:13-19.

Suzuki O., Koura M., Noguchi Y., Takano K., Yamamoto Y. \& Matsuda J. 2003. Optimization of superovulation induction by human menopausal gonadotropin in guinea pigs based on follicular waves and FSH-receptor homologies. Mol. Reprod. Dev. 64:219-225.

Tolosa E.M.C., Rodrigues C.J., Behemer O.A. \& Freitas-Neto A.G. 2003. Manual de Técnicas para Histologia Normal e Patológica. Manole, São Paulo. $341 \mathrm{p}$.

Váquez B. \& Del Sol M. 2010. Estudio morfológico de la próstata y glándulas vesiculares de cobayo (Cavia porcellus). Int. J. Morphol. 28:1301-1307. 